\title{
ZA PREMAGOVANJE POKLICNE IZGORELOSTI POTREBUIJEMO IZOBRAŽEVANJE \\ Osebni izobraževalni moduli za preprečevanje in zdravljenje izgorelosti (1. del)
}

\section{POVZETEK}

Izgorelost - in še posebno poklicna izgorelost - prizadene vse več ljudi. Nastane zaradi bremen, $s$ katerimi se spopadamo v življenju in/ali na delu. Izgorelost (angl. burnout) je bolezen tistega, ki se dolgo in vztrajno bori, ki se bori dlje in navadno bolje kakor drugi, za neko idejo, za nek način dela in življenja, za neke odnose. Je bolezen tistega, ki spozna, da ni v recipročnih odnosih $v$ delovnem in/ali zasebnem svetu. Če takšna borba traja dolgo, se lahko prelomi v izgorelost, kar škodi psihološkemu in fizičnemu zdravju osebe, pa tudi njenemu socialnemu in družinskemu okolju. V stanju izgorelosti pride do transformacije osebnosti, zamenjave vrednostnega sistema, iskanja novega odnosa do dela, ljudi in sveta. To stanje spremljajo čustvena in nevrološka kriza, različni somatski znaki, celo suicidalne misli. V njej nastanejo biološke, kemične, čustvene in kognitivne spremembe. Raziskave na tem področju so številne in zlagoma so raziskovalci uspeli podati uporabljivo in natančno definicijo izgorelosti, pregledati njene pojavne oblike, vzroke in posledice tega stanja z vidika osebe same, njenih delovnih odnosov in v širšem okolju ter glede na delovno organizacijo. Zbrana spoznanja lahko pripomorejo k oblikovanju izobraževalnih programov za preprečevanje in zdravljenje izgorelosti. Programov, s katerimi je moč izobraziti izobraževalce in zaposlene v podjetjih ter tako doseči primerne psihološke delovne pogoje, programov za ozavešcanje javnosti in osebnih izobraževalnih modulov, s katerimi spremljamo izgorele osebe na novi poti.

Ključne besede: poklicna izgorelost, izgorelost menedžerjev, burnout, transformacija osebnosti, nevrološke motnje, utrujenost, utrujenost sočutja, stres, preobremenjenost, varstvo pri delu, psihologija dela, samomor, zmožnosti, izobraževanje odraslih, usposabljanje

\section{METODOLOGIJA}

Znanstveno raziskovanje je tudi izkustveno raziskovanje tistega, kar smo, četudi nenamerno, doživeli, če smo izkustvo tudi opazovali, če sta temu sledila refleksija in preverjanje na
Doc. dr.

Dušana

Findeisen, Filozofska fakulteta v Ljubljani 
tov in hkrati opazovalke pojava. Spoznanja sem pridobila v svoji lastni krizi, z doživljajskim učenjem in s posledično racionalizacijo ter v tamkajšnjih različnih andragoških dejavnostih, v skupinski in individualni psihotera-

Z izobraževanjem do novega delovnega poleta. piji ter $\mathrm{v}$ osebnih pogovorih $\mathrm{z}$ nekaterimi, ki so se prav tako zaradi poklicne izčrpanosti znašli na tem oddelku. Po drugi strani sem do izsledkov prišla tudi z opazovanjem prakse. Gre za projekte spodbujanja zaposlenih za ponovno pridobitev delovne zmožnosti. Takšne projekte vodijo $\mathrm{v}$ francoskem izobraževalnem sistemu za poklicno izčrpane učitelje. Imajo jih tudi v zdravstvenih ustanovah, pa tudi podjetjih. Z njimi si z izobraževanjem zaposleni znova pridobijo delovni polet. Učijo se spreminjati odnos do dela, zajeziti delovno vnemo, reči ne in razporejati moči. Učijo se preusmeriti energijo $\mathrm{v}$ delo, ki ustreza njihovim močno spremenjenim vrednotam in transformirani osebnosti. Takšno izobraževa-

Delo se spreminja hitreje kot pravni instrumenti. nje sem opazovala v ARCADE v Nancyju, v ustanovi za izobraževalno osebje v stiski, kamor sem se podala, ker sem hotela pojav poklicne izčrpanosti bolje razumeti.

Spremljala sem tudi nekatere oddaje $\mathrm{v}$ arhivih radia France Culture in na Univerzi vsega znanja (fr. Université de tous les savoirs) ter pregledala literaturo in periodiko s področja psihologije dela.

Raziskava je poskus, da

(1) opredelimo pojem poklicne izčrpanosti in ga ločimo od drugih sorodnih pojmov,

(2) ugotovimo najpogostnejšse vzroke, značilnosti in posledice stanja poklicne izčrpanosti,

(3) preučimo možne izobraževalne teme za gradnjo osebnih in skupinskih izobraževalnih modulov in drugih programov za preprečevanje in zdravljenje poklicne izčrpanosti.
Z delovnimi pogoji so se doslej poleg delodajalcev, izobraževalcev v podjetjih in drugih ukvarjali predvsem sindikati in zavodi za varstvo pri delu. V mnogih evropskih državah podjetja tudi zaposlujejo svetovalce za preventivo na delovnem mestu in tako se razen njih izobraževanja za ustvarjanje boljših ali predpisanih delovnih pogojev udeležujejo tudi delodajalci, zaposleni, socialni delavci, kadrovski direktorji, tajnice, izobraževalci v podjetjih in drugi. Čas je, da premislimo o tem, kako psihološki pogoji dela vplivajo na nas in kako jih izboljšati s pomočjo izobraževanja.

\section{OSEBNI IN DRUŽBENI RAZLOGI ZA NASTANEK IZGORELOSTI}

Pravica do dela se je sprva utemeljila na pravni regulaciji zaščite delavčevega življenja. Ta naj ne bi postal žrtev pogodbe, skatero bi zastavil življenje in zdravje v zameno za plačilo, ki bi pokrilo zgolj njegovo delo. Vendar se delo spreminja hitreje kot pravni instrumenti, ki so jih uvedli zato, da bi nas zaščitili pred slabimi posledicami dela. Vprašanji, ki si ju v takšnih okoliščinah postavljajo mnogi strokovnjaki in tudi izobraževalci, pa sta naslednji: (1) Ali na delovnem mestu tvegamo, da izgubimo zdravje? in (2) Kaj nas pred izgubo zdravja varuje?

$\mathrm{Z}$ novimi koncepti dela in sredi prožnega kapitalizma se tudi izobraževanje za varstvo pri delu mora spremeniti.' Poklicne bolezni, nesreče pri delu, pravilniki o požarni varnosti, fizični zaščiti delavca, o vplivu sevanja ipd. - so vse te mreže socialne varnosti, ki smo jih zlagoma postavili na noge, da bi zaščitili zdravje zaposlenih, zdržale siloviti udarec korenite spremembe delovnih pogojev? Pomemben del zaščite delavcev so danes namreč tudi ustrezni psihološki pogoji dela, razporejenost obremenitev in način dela, ki naj zagotovijo osebnostno rast ter zadovoljenost primarnih in sekundarnih potreb delavcev in 
Več kot petindvajset let sem se ukvarjala z izobraževanjem odraslih in starejših odraslih ter mladih študentov. Domala sleherni dan sem vstopala $v$ življenje vsaj dvajsetih ljudi, spodbujala njihovo učenje in se istovetila z njihovimi potrebami, zanimanji, željami in težavami. Opravila sem na tisoče ur strokovnega prostovoljnega dela. Uvedla sem vrsto nacionalnih in mednarodnih projektov, odprla mnoga povsem nova področja. Domala sleherni mesec sem predavala $v$ drugi deželi, vodila hkrati več mednarodnih projektov, pisala številne članke, imela vrsto javnih predavanj, snovala izobraževalne programe in vodila izobraževanje odraslih na različnih področjih. Vrhu tega sem delovala še v izobraževalne gibanju, ki sem ga nekoč zasnovala. Bila sem na številnih konferencah ... jih organizirala ... Bila sem evropska izvedenka za izobraževanje starejših odraslih ... Bila sem v uredniškem odboru treh časopisov in revij ... Živela sem partnersko življenje med dvema mestoma v dveh državah, skrbela sem za več mladih ljudi ... bila na voljo prijateljem in znancem. Bila zmeraj na voljo. Pravim bila, kajti prav lahko se zgodi, da nikoli več ne bom prav zdrava in bom čas preživljala povsem drugače. Zakaj se je to zgodilo, zakaj me ni nihče znal opozoriti na nevarnost nevrološkega zloma, zakaj sem bila tako nevedna, zakaj so bili drugi tako nevedni? Zakaj $v$ našem prostoru ni ustreznih izobraževalnih programov, zakaj javnost ni ozaveščena? Zakaj nimamo specializiranih centrov za obravnavo tega pojava? Zakaj si ljudje ne upajo priznati izgorelosti v času, ko se izgorelost širi kot epidemija? In nenazadnje, zakaj je javnost tako neuka, da ne ločuje nevroloških motenj od duševnih bolezni? Zakaj je v sodobni evropski državi toliko predsodkov, kot da bi bili v srednjem veku?

delodajalcev. Vzrok slabih delovnih pogojev so tudi različni pojavi, ki jih obravnava psihologija dela: moralno preganjanje in šikaniranje na delovnem mestu (angl, mobbing), stres, preobremenjenost in nenazadnje poklicna izčrpanost oziroma izgorelost. Ta postaja vse pogostejša pri tistih, ki delajo z ljudmi - odvetnikih, svetovalcih, izobraževalcih, zaposlenih v uslužnostnih službah, menedžerjih in drugih, navadno pri najvztrajnejših, najinventivnejših in najproizvodnejših osebah. To izkazuje tudi moja osebna zgodba.

Biti na voljo in »teči tekmo sam s seboj je lahko naša notranja zapoved, tako kot v mojem primeru, lahko pa prihaja tudi od zunaj. ${ }^{2}$ Biti »popolnoma na voljo« je zahteva, ki si jo delodajalci postavljajo sami sebi in zaposlenim, tistim, ki imajo največ znanja, so najbolj inventivni in sposobni prevzeti nase največ odgovornosti. Zmožnost, da delajo cel dan, ob večerih, tudi ponoči, da neprestano potujejo in menjajo okolja, vse to se zdi povsem običajna razsežnost njihovega dela.

Še več, zdi se, da se v tem kaže le podoba njihove izbire poklicne poti, ki zahteva zavzemanje in predanost. Za nameček lahko vsemu pridamo še vrsto zahtev in pričakovanj

domačega okolja, prijateljev in nemalokrat tudi naključnih znancev. Na tistega, ki razvije zmožnosti, se »lepi« vse več in več.

Odgovorna delovna mesta zahtevajo prožnost in prilagajanje, zmožnost, da nadvse hitro obvladamo novo okolje, nova vprašanja, nove skupine sodelavcev, vse do dne, ko se ... zlomimo. Takrat je, če imamo srečo, diagnoza jasna: poklicna izěrpanost, poklicna izgorelost, suicidalne misli, mučna nevrološka kriza, hlad po celem telesu in občutek, da živci niso prekriti s kožo. Ob tem pride do Izgorelost na delovnem mestu se širi kot epidemija. bioloških, kemičnih, kognitivnih in čustvenih sprememb, ki so se nakazovale že prej, a jih ni nihče znal prepoznati. Od nikoder ni prišlo resno opozorilo, da naš nevrovegetativni živčni sistem tolikšnih obremenitev ne zdrži. Še več, tudi na naša opozorila in tožbe se ni nihče resno odzval. Tisti, ki so v vlogi svetilnika, le redko ali pozno dobijo pomoč. Zato ker jih socialno okolje potrebuje $\mathrm{v}$ njihovi vlogi in ker so zvečine zmeraj sami našli rešitve. Zanje preprosto velja, da zmorejo brez pomoči. Da je mera polna, navadno tudi pomoči ne znajo dobro sprejeti. 


\section{OPREDELITEV POIKLICNE IZČRPANOSTI OZIROMA IZGORELOSTI}

Močna negativna čustva so najboljši znak, da so naše obnašanje in pričakovanja $v$ neskladju s stvarnostjo. Razdražljivost, jeza, bes, žalost, ki spremljajo stanje izgorelosti, razkrijejo tisto, kar skrivamo v sebi. Čustva in obnašanje verno izkazujejo naše vrednote. Izgorelost je hkrati čustvena in nevrološka kriza, je kriza vrednot, v kateri nam močna čustva razkrijejo, kaj nam je resnično pomembno in vredno ter kaj bomo morali spremeniti. ${ }^{3}$

Iztrošenost, izrabljenost, poklicna izčrpanost, izgorelost (angl. burnout). Izrazi se spremi-

Vprašajmo se, kaj

je za nas resnično pomembno.

njajo glede na okolje, v katerem jih uporabljajo. Pojem burnout je prvi uvedel Bradely (1969). Z njim poimenuje poseben stres, ki izhaja iz dela. Nekaj let kasneje izraz povzameta Herbert Freudenberger (1974) in Maslach (1976) ter z njim znova poimenujeta pojav poklicne izčrpanosti oziroma izgorelosti na delovnem mestu. Za te prve opazovalce pojava je bila izgorelost predvsem stanje zdravstvenih delavcev, socialnih delavcev, izobraževalcev in odvetnikov, ali drugače povedano, onih, katerih delo zahteva srečevanje

\section{Izgorelost je najpo- gostejša v poklicih, ki delajo z ljudmi.}

ljudi. V tistih časih so burnout opredelili kot psihološki sindrom, ki se pojavi v spomočnih« poklicih. Burnout pa je precej širši pojav. Človek lahko izgori zaradi različnih, trajajočih vzrokov, ti pa so zmeraj v povezavi z njegovim vztrajnim prizadevanjem, odrekanjem, pričakovanji, s psiho-socialnimi odnosi, ki jih spremljajo, pa tudi z njegovim subjektivnim načinom doživljanja.

Preden se je izraz burnout razprostranil, smo zmotno govorili o stresu ali preobremenitvi. Dandanes se beseda stres ohranja v naslovih programov izobraževanja in usposabljanja, najverjetneje zato, ker se ob njej nihče - niti posamezniki niti ustanove - ne počuti kriv za nastanek poklicne izčrpanosti.

Izraz preobremenjenost se zdi preozek. Ne pove bistvenega, da se v stanju burnouta motnje pokažejo hkrati v vseh zmožnostih, $\mathrm{ki}$ jih imamo. Preučevanje slovarskih opredelitev pokaže, da gre za »posledice pretirane utrujenosti; za različne težave, ki nastajajo zaradi prevelikega obsega dela«. Lahko smo preobremenjeni takrat, ko je veliko dela, vendarle to še ne pove, da gre za trajnejše stanje, v katerem nekdo povsem izgubi zmožnost pozitivnega odzivanja na situacije. Še več, ta opredelitev nas navaja na sklep, da gre za prekoračitev, pretiravanje, ne opozarja pa nas na to, da se nekdo s težavo prilagaja delu, ki ga želi opraviti. Prav vprašanje prilagajanja se je pokazalo kot bistveno v burnoutu. V tem stanju namreč frustracijska tóleranca močno upade.

Poklicna izčrpanost oziroma izgorelost. V izčrpanosti gre za »izgubo telesnih in moralnih moči« za uničenje telesnih moči, življenjske energije, Ta izraz prikaže izgubo energije, ki nastane zaradi izgorelosti, pri čemer se pokažejo simptomi, ki so dokaj podobni depresiji. Lahko se sicer zgodi, da se izčrpanemu človeku svet ne zdi grozeč, podoba, ki jo ima o sebi, ni okrnjena, jasno se zaveda svoje vrednosti in uspešnosti, ni pa več zmožen mirno obvladovati odnosov in se prilagajati. Pojavijo se jeza, bes in sovražnost, občutek izrabljenosti. Če prav pomislimo, so ta čustva tudi razumljiva, saj človeka branijo pred prilagajanjem socialnemu in delovnemu okolju, prilagajanjem, ki ga ni več sposoben, kajti v tem stanju potrebuje vso silo zase in zgolj zase. Pogosto mu tečejo solze. Ima občutek odvečnosti in nerazumljenosti. Iz sveta, ki se mu ne more več prilagajati, bi najraje izstopil. Zato, ker ne zmore predrugačiti odnosa do dela in ljudi. Svojemu svetu želi postaviti nove meje, pa tega ne zmore, v starih pa spoka«, tako kot kača, ki se želi izmotati iz svoje kože, ki jo 
»Stanje izčrpanosti je stanje, v katerem se organizem ne more več braniti ali prilagoditi prevelikim pritiskom in napadom nase, pa naj bodo ti te ali one narave ... Ko delamo, nam dejstvo, da smo za delo motivirani, pomaga sprostiti zmožnosti za še nekaj več prilagajanja, pri čemer ni pomembno, če smo motivirani zaradi poklicne vesti, osebnih stremljenj ali zaradi tekmovalnih situacij, s katerimi se srečujemo. Če se ne moremo več prilagajati, če zalogo zmožnosti prilagajanja izčrpamo, smo preobremenjeni in izčrpani. Ko se to zgodi, pa se ne moremo več prilagajati, kar povzroči biološke in organske motnje.«

tesni. Kasneje prične jasno čutiti, da se spreminja; ima občutek, podoben tistemu pri igri $\mathrm{z}$ mikado paličicami. Kot da je nekdo iz mreže padlih paličic nekatere dolgo vlekel, pa se ni zgodilo nič, vse dokler ni izvlekel ene paličice preveč in se je struktura padlih paličic dokončno razbila. Zdaj bo treba paličice zbrati, jih ponovno vreči in dobili bomo novo kombinacijo, novo celoto. Ta pa bo povsem drugačna. Do nje bodo igralci morali zavzeti nov odnos.

Najvidnejša posledica izčrpanosti se kaže v brezosebnem načinu opravljanja dela in pojavu vzvišenosti. Človeku ni več do tega, da bi napredoval, da bi reševal stvari na svoj način, da bi bil ustvarjalen. Socialne igre ga ne zanimajo več. Zgubi spoštovanje do prizadevanj večine ljudi. Izobraževanje za preprečevanje poklicne izčrpanosti mora tako poseči tudi $\mathrm{v}$ spreminjanje delovnega okolja in ne le osebe same.

Če zdaj povzamemo: burnout $\mathrm{v}$ angleščini pomeni iztrošiti se, utruditi se, zlomiti se, izgoreti zato, ker je zahtev preveč, ker je zahtev po tem, da smo močni in da izrabimo vse svoje moči in znanje, preveč.

Freudenberger, ki je sam doživel burnout, in Richelson leta 1980 ta pojav opišeta takole:
Stanje kronične utrujenosti, depresije in frustriranosti, do česar pride, ker je oseba predana neki ideji, nekemu načinu življenja ali nekemu odnosu, od koder nazadnje ne dobi pričakovane nagrade. Takrat se zmanjša njena delovna vnema in zmanjšajo se delovni dosežki (str. 13).

\section{NASTANEK IZGORELOSTI, VZROKI ZANJO, NJENE POIAVNE OBLIKE IN POSLEDICE}

Prve znake poznamo razmeroma dobro, saj so $\mathrm{v}$ povezavi s poklicnim stresom dobro popisani. Povezava med dolgotrajnim poklicnim stresom in izgorelostjo pa je manj jasna. Če stres traja več let, privede do izčrpanja energije za delovanje, saj se ta ne more načrpati. Viri energije so dejavnosti in odnosi, ki povzročajo ugodje in radost, ob katerih se sproščamo. Prav tega izgoreli človek ni več

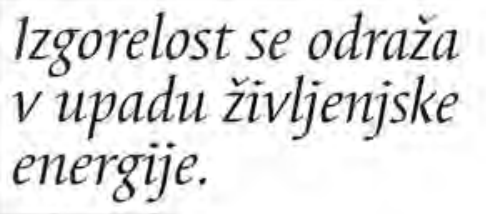
sposoben, kajti preveč je utrujen. Nič več ne občuti ugodja in veselja, ne želi si ničesar več. Še zmeraj si prizadeva pri delu in v svojem socialnem okolju, vendar ga to ne radosti. Svet se mu zdi dolgočasen, naporen, monoton. Ko so težave že zares navzoče, pa se zjutraj zbuja enako utrujen, kot je legel spat, pogosto se prebuja ponoči, tlači ga mora, sili ga na bruhanje, ima mravljince $v$ konicah prstov in v ustnicah, $\mathrm{v}$ tilniku čuti napetost, obliva ga hlad, zgubi tek ali pa ga popade silna želja po hrani, ima

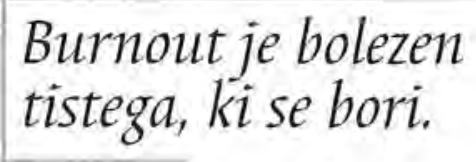
prebavne motnje. Nazadnje bolečina preplavi vse sfere njegovega bitja; telesno, čustveno, miselno in celo duhovno. Vse manj nadzira življenje. Težko se odloča in odločitve niso najbolj razsodne. Lahko se ga lotijo smrtne bolezni, zaradi nepozornosti in utrujenosti se mu godijo nesreče. Teže obvladuje socialne stike. Lahko se jih prične ogibati ali pa postane razdražljiv in napadalen. Utrujenost vpliva 
tudi na spoznavne zmožnosti in sposobnost osredotočenja popusti. Spomin slabi.

Če nekdo z bolečino dolgo ne opravi, se lahko osebnostno močno spremeni. Kadar bolečina dolgo traja - navadno leta dolgo -, se ogiba vsega, kar bi ga veselilo ali česar bi si lahko želel, ker bi to lahko njegovo bolečino in trpljenje še povečalo. Tisti, ki opravljajo poklice $z$ ljudmi in za njih, lahko tako nezavedno pričnejo zanikati odnose. Njihov odnos lahko postane škodljiv za tiste, s katerimi

\section{Do izgorelosti pri- haja tudi zato, ker delo ni v skladu z našimi (novimi) vrednotami.}

ga navezuje. Lahko postanejo razdražljivi, nasilni ali pa nasprotno povsem neprizadeti, ne da bi to hoteli, marveč zato, ker drugače ne morejo. Tedaj se niso sposobni ali niso željni udeležiti izobraževanja, s katerim bi si lahko popravili vedenje. Zdi se, kot da s skrajnimi močmi lovijo ravnotežje. V takšnih primerih izobraževalci pri njih težko dosežejo, da bi odnos do dela in svojega socialnega okolja spremenili.

Stanje poklicne izčrpanosti je nujna etapa v procesu spreminjanja. Nastanek bolezenskega stanja in prekinitev dela nazadnje človeka prisili, da se zazre vase, česar vse, dokler je bilo delo v polnem teku, ni mogel.

Poklicna izčrpanost ni neizogibna. Lahko se je ognemo, če sami sebi ali pa če delodajalci ne nalagajo dela brez premisleka, če sami upoštevamo svojo potrebo po razvoju, ali jo, če smo zaposleni, upoštevajo delodajalci. Vendar se lahko zgodi, da nekdo sam ugotovi, da $z$ delom ni več zadovoljen, pa vendar $v$ delu in delovnih pogojih vztraja, ker pač nima moči za spreminjanje položaja. Zato je pomembno, da izobraževanje za zdravljenje izgorelosti spremlja tudi poklicno in pravno svetovanje skupaj, seveda s podporo psihologa in psihoterapevta. Ta naj osebi pomagata, da ozavesti nove vrednote, ki nastanejo s pomočjo stanja izgorelosti. Delo, ki ga oseba opravlja po takšnem stanju, naj bo na novih področjih, kjer je nove vrednote moč uveljaviti.

Ločnice v poklicnem življenju. Poklicna izčrpanost lahko nastane predvsem pred vstopom $v$ poklic, $v$ času, ko izberemo poklic, ob vstopu v poklic in ob soočenju z realnostjo ter tudi v sredini življenja, ko poklic že obvladamo in se pojavi potreba po razvoju.

Poklicna izčrpanost je $\mathrm{v}$ povezavi s tem, kako se zavzemamo v poklicu, kako si prizadevamo in tudi s tem, koliko smo se sposobni zdravo oddaljiti od svojega dela. Zdi se, da vse izhaja iz otroštva, ko se nam oblikujejo pogledi na družbo, ko se odprejo najpomembnejša življenjska vprašanja in želja, da bi vplivali na svet. Tisti, ki lahko potonejo v izgorelost, so navadno hipersocializirani. Že kot otroci so sami zase sklenili, in takšno je bilo tudi pričakovanje njihovega okolja, da je njihovo poslanstvo v skrbi za druge, njihove potrebe, ugodje in čustva. Njihove potrebe so bile zmeraj nekje daleč zadaj, pogosto so bili ločeni od svojih želja, tako je tudi v odraslem obdobju. Vse, kar so storili in dosegli - ponavadi gre za nadpovprečne dosežke -, se jim zdi naravno in razumljivo, iz tega ne črpajo samospoštovanja. Kot da so jim čustva do samega sebe prepovedana. Še več, doživljajo jih predvsem tako, da drugim omogočijo napredek, radost, odkrivanje.

Družinsko okolje vpliva na poklic, ki ga izberemo. Glede na položaj, ki smo ga zavzeli do družinske zgodbe - nadaljevanje, spreminjanje -, se oblikuje tudi odnos do dela. Tako je z osebnimi izobraževalnimi moduli pomembno privesti izgorelo osebo $v$ razmislek o tem, na kakšen način se želi vkjjučiti v družbo, kaj osebnega želi razviti in kako lahko deluje $\mathrm{v}$ poklicnem okolju. V času izobraževanja je dobro načeti vprašanja, s katerimi se bo človek po povratku v okolje srečal, tako da se bo lahko izognil pretresu ob stiku s stvarnostjo. Človek se s poklicno stvarnostjo največkrat sreča v prvih letih poklicne zaposlitve.

Kako vstopi v poklic, je odločilnega pomena za njegovo prihodnost. Po nekaj letih stvarno 


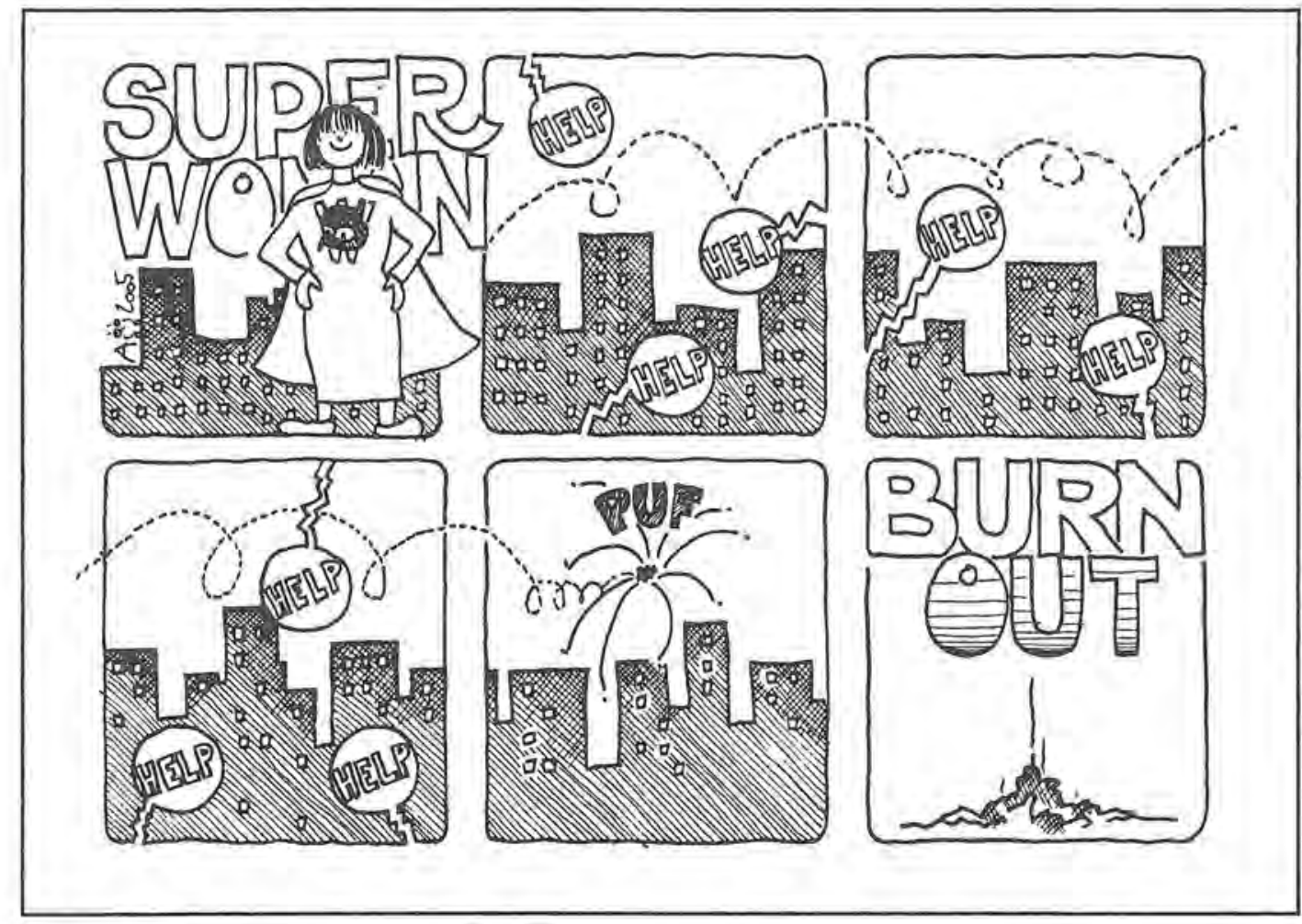

obvlada svoje delo, zlagoma preide od idealizirane podobe poklica $\mathrm{v}$ resnično spreminjanje na poklicnem področju ali pa se marsičesa odreče in tone v poklicno izčrpanost.

Prva leta botrujejo trdnosti ali rahlosti, ki se bo pri nekom kazala tudi kasneje. Preprečevanje poklicne izčrpanosti je tedaj mogoče že pri mladih v preizkusni dobi. Kako učinkovito je, je odvisno od mentorstva, ki so ga deležni. Č je dobro, profesionalizacija poteka skladno in pridobi si moči in sredstva, $s$ katerimi se Iahko upre poklicni izčrpanosti.

Pogoji za obnovo zmožnosti. Čas, ki je potreben za to, da se zmožnosti obnovijo, je močno odvisen od pomoči in spremljanja (angl. coaching) tistega, ki je poklicno izčrpan. Včasih, tako se zdi, se bolečina in trpljenje pri nekom javljata ves čas vzdolž poklicne poti, tako da se ju človek niti več ne zaveda. Drugi spet se izčrpanosti zavedo razmeroma hitro, saj jim pri tem pomaga poklicno okolje. Vsaka etapa lahko traja od nekaj mesecev do nekaj let, odvisno od tega, kako dobro spremljamo izčrpano osebo. Včasih se proces odvija, potem pa zastane in človek ne zna napredovati sam brez opore. Tako morata biti izpolnjena dva pogoja, da se mu povrnejo zmožnosti: najti mora način, da si odpočije in ta počitek traja, pri tem pa ni ogroženo njegovo delovno mesto oziroma delo, potrebno pa je tudi dobro spremljanje, ki človeku omogoči, da oblikuje nov načrt za življenje.

Načrt mora biti dovolj prožen, da si lahko oseba premisli, če opazi, da ni uresničljiv. Nekdo, ki je šel skozi stanje poklicne izčrpanosti, čuti, da se mora varovati. Poklicna izčrpanost namreč v njem sproži tako hudo bolečino in trpljenje, da je njegovo življenjsko ravnovesje ogroženo. Ce to stanje traja, je lahko ogroženo tudi njegovo življenje.

Obnova zmožnosti je tako odvisna od prepričanja, ki ga nekdo doseže, da bo zmožen speljati nove načrte in poklicno pot. Če se teh načrtov ne loti s premislekom, se lahko zgo- 
di, da ne uspe in tedaj povsem izgubi nadzor nad svojim življenjem. Nadvse pomembno je, da preveri stvarnost svojega načrta. Lahko se zgodi, da je načrt namenjen predvsem temu,

\section{Družbeno okoljes svojimi spremem- bami spodbuja pojav izgorelosti.} da izrazi bistvo samega sebe, in manj temu, da se vključi $v$ družbo. Oblikovanje načrta mora vsebovati tudi vprašanje o tem, kaj je tej osebi vredno, kaj bo naredilo njeno življenje vredno. Nekatere dejavnosti, ki jih sprva opravlja prostovoljno, so lahko dober začetek za novo poklicno življenje. Za nekatere dejstvo, da se vračajo k radostim, ki so jih občutili v času odraščanja, služi kot začetek nove poklicne poti. Za vse pa načrt pomeni, da se bodo lahko na nov način izrazili v đružbenem življenju.

\section{VPLIV DELOVNEGA IN SOCIALNEGA OKOLJA NA NASTANEK IZČRPANOSTI OZIROMA IZGORELOSTI}

Raziskovalci poklicne izčrpanosti so se komaj nedavno posvetili okolju, v katerem se odnosi odvijajo. Preučevanje poklicnih pričakovanj institucij, vodenja institucij, družbenih okoliščin in sprememb pripomore $\mathrm{k}$ razumevanju nastanka poklicne izčrpanosti. Med spremembe se uvrščajo rastoči individualizem, zmanjšanje spoštljive razdalje do drugega, upad ugleda nekaterih poklicev, čaščenje zrele mladosti, povečanje prostora za
Poklicna izcrpanost vpliva na odločitve, ki jih strokovnjaki sprejmejo glede oseb, ki potrebujejo pomoč. Poklicno izčrpani strokovnjaki so manj zavzeti, kažejo manj zanimanja, čutijo razdaljo med seboj in tistim, ki potrebuje pomoč. Zaradi poklicne izčrpanosti se odločijo, da bodo manj »vložili« v drugega. Zato je za njih pomembno, da oni, ki pomoč potrebuje, sodeluje. Če tega ne stori, v strokovnjaku budi negativna občutja.

manipulacije vseh vrst, nadomeščanje kulture z modnimi pojavi, brisanje zgodovine in dojemanje zgodovine kot niza dogodkov, nastanek "prožnega kapitalizma«. ${ }^{4}$

Pogosto je govor o poklicni izčrpanosti medicinskega osebja. Pacienti se z njimi srečujejo, pričakujoč pomoč, ki naj bi jim jo dali po medicinskem modelu in/ali modelu socialne kompenzacije. Medicinski model je za medicinsko osebje precej manj izčrpavajoč, model socialne kompenzacije pa je precej manj izčrpavajoč za socialne delavce. Gre za poklicna pričakovanja enih in drugih, ki so različna, Razkorak med modelom dajanja pomoči in poklicnimi pričakovanji je lahko vir poklicne izčrpanosti. ${ }^{6} \mathrm{~V}$ osvetlitev te trditve povejmo, da denimo medicinske sestre alkoholika dosti laže obravnavajo kot obolelega človeka in dosti težje kot človeka, ki potrebuje socialno pomoč. Za socialne delavce pa velja ravno nasprotno.

Poklicna pričakovanja strokovnjakov so seve-

Zgodnje raziskave zmotno poudarjajo, da do izčrpanosti pride le v odnosih dajanja pomoči, in jih pripisujejo predvsem lastnostim strokovnjakov pomočnikov in prejemnikov pomoči. Strokovnjak, ki nudi pomoč, je namreč občutljiv za sodelovanje onih, ki pomoč prejemajo. Če se slednji svojih težav lotevajo na način, ki ne ustreza strokovnjakovi predstavi, lahko ta z njimi sproži konfliktni odnos. To lahko pri njem pospeši nastanek poklicne izčrpanosti. Če se prejemniki pomoči ne vdenejo v strokovnjakov model dajanja in prejemanja pomoči, jih ta kaj kmalu proglasi za nesodelovalne, težavne ali neprizadete. Tedaj lahko strokovnjak dajalec pomoči še bolj trdo poskuša socializirati osebe, potrebne pomoči, ali pa se jih prične ogibati, kar ustvarja nove težave in nered (Karuza idr., 1982, str. 123, Truchot, 1994).5 
Organizacija nalog in vlog je v marsikateri ustanovi takšna, da zaposleni ne morejo dojeti povezave med svojimi dejanji in cilji organizacije. Če posamezniki niso dovolj avtonomni v odločanju, če ne prejmejo dovolj informacij in podpore predpostavljenih, izgubijo občutek, da so učinkoviti. Tudi to je vir poklicne izčrpanosti. Dojeti morajo kratkoročne in dolgoročne cilje. Delovna organizacija, ki si želi, da bi bili zaposleni učinkovitejši, mora to spoznanje upoštevati. Podpora zaposlenim na delovnem mestu bo preprečila nastanek poklicne izčrpanosti.

da bolj posledica institucionalne doktrine kot strokovnjakov samih. Strokovnjaki se namreč nazadnje povsem podredijo institucionalnim pričakovanjem. Tako navadno pomagajo le s sredstvi pomoči, ki jih zagotavlja njihova ustanova. Zaznavanje osebe, ki pomoč potrebuje, je tako odvisno od tega, kar zmore institucija (Batson, Jones, Cochran, 1979).

Močan vir poklicne izčrpanosti, ki je nasledek trajnih napetosti in stresa - četudi ne gre za močan stres -, je tudi soočanje z osebami, ki so preživele različne travme. V mislih imamo gasilce, socialne delavce, terapevte, medicinske sestre, zdravnike, policaje, ki dan za dnem poslušajo krute pripovedi o nesrečah, mučenju, posilstvu, krvoskrunstvu, nasilju v družini, $\mathrm{v}$ zakonskem paru in se morajo nanje odzvati. Ti strokovnjaki lahko posledično tudi sami občutijo težo travmatičnega dogodka in spremljajočih čustev. Zlagoma lahko pri njih pride do STS, $t j$. sekundarnega travmatičnega stresa. Ta je podoben poklicni izčrpanosti po tem, da nastaja zaradi dolgotrajne izpostavljenosti mislim, podobam, dogodkom, ki so lahko premočni, da bi se strokovnjak še prilagajal. Strokovnjaki tudi fiziološko reagirajo na pripovedi onih, ki iščejo pomoč. Njihovo čustveno stanje je pri tem nenehno neugodno (Figley, 1983, Cerney, 1995).

V literaturi omenjajo tudi utrujenost sočutnosti (Figley, 1995), do katere prihaja predvsem pri tistih, ki dan za dnem poslušajo pacientove zgodbe, denimo o spolni zlorabljenosti. Gre za razumljivo in naravno obnašanje ter čustva, ki izvirajo iz poznavanja travmatičnih dogodkov, ki jih pacient občuti, in za stres, ki je pri strokovnjaku nasledek pomoči ali želje, da bi travmatizirani osebi nudil pomoč (Figley, 1983). Še več, »oni, ki imajo velike zmožnosti, da začutijo in izrazijo empatijo, so pogosteje žrtve utrujenosti sočutja«. Tedaj se ne ustavijo pri sočutju, marveč poskusajo tudi kaj storiti, da prizadeti osebi zmanjšajo bolečino. Osebe, ki zapadejo v stanje poklicne izčrpanosti, so pogosto žrtve svoje zavzetosti za pomoč prizadetim osebam.

Sektor storitev je najobsežnejši gospodarski sektor. Delo v tem sektorju temelji na odnosih z ljudmi in tu se posledično sproža več nasilja kot drugod. Več nasilja srečujemo pri (1) osamljenih delih, denimo pri oskrbovalcih na domu, voznikih taksija ali avtobusa, zaposlenih na bencinskih črpalkah, trgovcih v majhnih trgovinah; (2) pri rokovanju z denarjem ali dragocenimi predmeti, tj. blagajnikih, bančnih uslužbencih, varnostnikih, lekarnarjih, (3) pri opravljanju nadzornih del, tj. pri prometnikih, policajih, nadzornikih parkiranja, (4) pri delu v sektorju dajanja pomoči, izobraževanja, svetovanja ali v stiku z marginaliziranimi družbenimi skupinami. Tu gre za medicinsko osebje, izobraževalce, socialne delavce, advokate idr. Nasilje na delovnem mestu je psihološke in moralne narave (agresivnost, žalitve, grožnje, moralno preganjanje) ali telesne narave (pljuvanje, udarci, rane, umori ...). Žrtve nasilnih dejanj preživljajo posttravmatični stres. Vendarle pa so besedna agresivnost - grožnje, žalitve - provokacije, nevljudno obnašanje, če trajajo dlje, vir poklicne izčrpanosti. ${ }^{7}$

$\mathrm{V}$ literaturi zasledimo bolj malo o tem, kako 
procesi v delovni organizaciji boljšajo odnose s strankami, kupci, študenti, prejemniki pomoči ... kako boljše storitve vplivajo na

Pojav poklicne izgorelosti je odvisen tudi od načina vodenja.

preprečevanje poklicne izčrpanosti, kako se na ta način manjšajo napetosti. Hemmelgar, Glisson in Dukes (2001) so odkrili, da če imajo zaposleni strokovnjaki pozitiven odnos do delovnega okolja,

bodo tudi bolje delali. Način, na katerega strokovnjaki zaznajo uporabnike storitev, pa je odvisen od tega, če odnose v svoji delovni organizaciji zaznavajo kot pravične. ${ }^{8}$

Raziskave o poklicni izěrpanosti navadno ne zastanejo pri vprašanjih vodenja in vodstva delovne organizacije, od česar pa je vse odvisno. Nezmožnost uveljavljanja svojih zmožnosti, avtonomnost in nadzor nad dogajanji lahko napovedo poklicno izčrpanost. Nastop izčrpanosti zaposlenih je v marsičem odvisen od načina vodenja in izvajanja oblasti $v$ delovnem okolju. ${ }^{9} \mathrm{~V}$ odnosih v delovni organizaciji je potrebno doseči in vzdrževati ravnotežje in pravičnost, pa naj gre za odnose $\mathrm{z}$ uporabniki, strankami, odnose s sodelavci ali organizacijo samo. Tako mora biti izobraževanje za preprečevanje in zdravljenje izgorelosti namenjeno tudi delodajalcem in vodstvenim kadrom. V teorijah družbene menjave (Blau, 1964) velja, da je vsaka interakcija menjava

Absentizem je često odgovor na to, da smo zaznali nepravičnost. psiholoških nagrad (priznavanje, družbeni status), kazni (žalitve, izstop iz odnosa) in stvarnilh dobrin (denar). $\mathrm{Na}$ te menjave so posamezniki posebej pozorni, kajti na njih je utemeljeno občutje pravičnosti, ugodja in ravnovesja. Teorija pravičnosti (Adams, 1965) se močno povezuje $\mathrm{z}$ vprašanji poklicne izčrpanosti oziroma izgorelosti. Vse, kar vložimo v odnos, lahko obravnavamo kot strošek: porabljen čas, energijo, izobrazbo, kulturo, izkušnje, iskanje inventivnih rešitev, druženje z drugimi. Če nekdo zazna, da je med vložkom in nasledkom neravnotežje in da je neravnotežje med vložki in nasledki drugih, s katerimi se primerja, tedaj se mu zdi, da je to nepravično. Če vlaga preveč, se počuti opeharjenega, če vlaga premalo, se počuti krivega. V obeh primerih lahko to vodi $v$ poklicno izčrpanost oziroma izgorelost.

Stanje pravičnosti je moč znova vzpostaviti tako, da zmanjšamo vložek, delamo manj, preživimo manj časa s tistimi, ki potrebujejo naše storitve, manj pomagamo sodelavcem, porabimo manj moči za delovno organizacijo. Lahko pa tudi poiščemo nove pritoke: zahtevamo povišico, izsilimo priznanja, si prisvojimo drobne in manj drobne reči ali poskušamo omalovaževati prednosti drugega, ga spravimo na slab glas ipd. Zaznavanje nepravičnosti vpliva na nas in našo pripadnost delovni organizaciji (Organ in Moorman, 1993). Kaže se v pogostnejši odsotnosti z dela. Zaposleni lahko o sebi misli bolje, kot je upravičeno, ali pa delovno razmerje prekine, če predolgo zaznava neravnotežje med naporom, ki ga vlaga, in nagrado, ki jo iz dela dobi. Vendarle zaposleni to včasih težko stori, zato največkrat ne odpove delovnega razmerja, pač pa prične manj zavzeto delati. Sicer pa ima poklicna izčrpanost oziroma izgorelost še eno značilnost: oseba je neprizadeta, ne čuti več osebnega odnosa do dela, sodelavcev in organizacije, cinična je. To $v$ stanju izčrpanosti mora storiti, da tako vzpostavi razdaljo med seboj in situacijami. Takrat postane precej manj zavzeta pri delu in tako nastane škoda za delovno okolje osebe.

Ko nekdo ugotovi, da njegovi napori in zav zetost za delovno organizacijo ne pomenijo kaj dosti in za to ne prejme nagrade, to vodi

Danes vemo, da lahko občutje neravnotežja, nepravičnosti, nepoštenosti v odnosih vodi $v$ stanje poklicne izčrpanosti in da se temu lahko izognemo, če si pravočasno pridobimo znanje o tem. 
$\mathrm{v}$ frustriranost in oběutje, da se mu godi krivica. Podjetja morajo z zaposlenimi skleniti neke vrste »psihološko pogodbo«, v kateri se zapiše, kaj zaposleni pričakuje, kakšen odnos recipročnosti $\mathrm{z}$ delovno organizacijo ima $\mathrm{v}$ mislih. Če te recipročnosti ni dovolj, je tudi to vir poklicne izčrpanosti. Še več, takšno delovno organizacijo zaposleni pogosto zapustijo. Pogosto so odsotni zaradi bolezni, nezadovoljni so $\mathrm{z}$ delom, prisvajajo si drobne stvari. Izkazujejo cinizem in manj zavzetosti pri delu. Premajhna recipročnost med zaposlenim in delovno organizacijo je posledica negativne komunikacije z vodstvom. Vpliv premajhne recipročnosti na stanje poklicne izčrpanosti oziroma izgorelosti se prav posebej kaže pri določenih populacijah (izobraževalci, medicinske sestre, socialni delavci itd.).

Dolgotrajna šibka recipročnost med delavcem in delovno organizacijo lahko vodi $\mathrm{v}$ obup (čustveno izčrpanost, tožbe glede slabega zdravja), umikanje, odsotnost zaradi bolezni, psihološki umik, majhno zavzetost za vprašanja organizacije ipd.

Premajhna recipročnost med zaposlenim in delovno organizacijo pa ni edini vzrok za to, da pride do izgorelosti. Nekdo lahko izgori tudi zaradi zasebnih odnosov. Trudi se, odnosu daruje čas, napor, izkušnje, znanje, spretnosti, energijo, kulturo, empatijo ... razumevanje. Nazadnje ugotovi, da drugi tega pravzaprav ni opazil. Da je opazil zgolj dejanja, da je bil zanj odnos predvsem prijeten in potreben. Da ga je vzdrževal z dejanji, bolj malo pa z vživljanjem. Tedaj človek iznenada pride do spoznanja, da ga drugi $v$ dolgih letih ni uspel niti spoznati niti zares razumeti. Tudi $v$ dolgotrajnih zasebnih odnosih - partnerskih, družinskih in prijateljskih odnosih - lahko doživimo utrujajoče nerecipročne odnose. Takšno spoznanje je prav tako vir izgorelosti.

Siegrist (1991) je razvil model neravnotežja med prizadevanjem in nagradami. Ta pisec se zanima predvsem za odnose $\mathrm{z}$ delovno organizacijo. Siegrist pravi, da človek zadovoljuje svoje temeljne potrebe - denimo potrebo po spoštovanju samega sebe - da pridobi občutek, da je učinkovit le v povezavi $z$ neko socialno strukturo. Ta mu omogoči, da pripada zanj pomembnim skupinam, daje mu možnost delovanja, potrjevanja osebnosti. $\mathrm{Da}$ bi nekdo dobil potrdila zase, za svoje bitje, pa je potrebno vzpostaviti sistem recipročnosti. Nagrade, ki prihajajo iz dela, so nadomestilo za delavčev napor. Nesorazmerje med napori in nagradami je pogosto $v$ storitvenih dejavnostih, še posebno tistih, kjer je veliko stika z uporabniki storitev.

Delavec od organiziranega dela pričakuje pričakovani izkupiček: denar, spoštovanje - podporo, pravičen odnos do sebe - in možnosti poklicnega vzpona, $\mathrm{t}$. nadzor nad svojim poklicnim položajem - varnost, delo

Delo od nas zahteva napor, napor, ki je naložen od zunaj ali si ga naložimo sami, pravi Siegfrist. Med napore, naložene od zunaj, se uvrščajo: prilagajanje časovnim omejitvam, nestalnost, nalaganje odgovornosti, potreba po delu prek delovnega časa, fizična obremenitev, povečanje povpraševanja po izdelku ali storitvi, zmeraj novi projekti, potreba po neprestanem učenju. Napor, ki si ga naložimo sami, pa je v povezavi z našimi psihološkimi lastnostmi: z našo potrebo po tem, da nas priznajo, s tekmovalnostjo, ki nas žene, s skrito sovražnostjo $\mathrm{v}$ nas, z nestrpnostjo, ki jo občutimo, in z močno razdraženostjo, nezmožnostjo, da vse pustimo preprosto za seboj in odidemo. Tak napor si naložijo osebe, ki imajo potrebo po nadzoru. Tisti, ki občutijo to potrebo, so bolj zavzeti pri delu, uporabijo vse moči tudi v situacijah, kjer te niso neizogibno potrebne. 
primerno izobrazbi, možnosti napredovanja. Kadar pride pri nekom do neravnotežja med pričakovanimi nagradami in vloženim naporom, njegova pričakovanja niso izpolnjena in to ga naredi napetega. Postane čustveno in fiziološko nestabilen.

Ta model kaže na to, da ljudje $v$ nekaterih delovnih situacijah vztrajajo, da so izpostavljeni

Poklicna izčrpanost je »nalezljiva«. nenehnemu stresu: (1) vztrajajo $\mathrm{v}$ neugodnih delovnih situacijah, ko je veliko brezposelnih in dela ni moč najti, ko gre mobilnost navzdol, (2) v situacijah, ko zaposleni sprejmejo neravnotežje, čakajoč na boljše čase, na napredovanje, na prihodnje nagrade in priznanja, (3) kadar imajo poseben vzorec soočanja s stresom, ko ob večjih zahtevah še povečajo napore, da bi bile le deležne priznanja. Te osebe izkazujejo odnos in obnašanje ter čustva, ki spremljajo pretirane napore. Pri tem si želijo, da bi dobile priznanje in bile spoštovane. Napetost se preprosto prenaša z

$V$ stanju izgorelosti potrebujemo socialno in čustveno oporo. enega zaposlenega na drugega. Gre za nalezljivost negativnih čustev, kajti sodelavci, ki prepoznajo sodelavca, ki je poklicno izčrpan, si njegovo stanje pripišejo. Negativna čustva se hitreje prenašajo kot pozitivna. Zlagoma lahko pride do kolektivne poklicne izčrpanosti zaradi delovnih zahtev. Tako se izgorelost nakopiči $\nabla$ nekaterih skupinah tudi ne glede na delovne pogoje.

Število odnosov in priložnosti, da igramo po- membne socialne vloge, je bistvenega pomena za delo. Ti odnosi so danes $\mathrm{v}$ času novih tehnologij še toliko pomembnejši, kajti število teh se manjša. Delo na daljavo prečrta odnose s sodelavci. Začasno delo, ki teče $z$ več podjetji hkrati, prav tako. Tudi osebni odnosi $v$ zakonu in družini manjšajo ali večajo možnosti poklicne izčrpanosti ali izgorelosti.

Pomembno vlogo, še posebno $v$ zdravljenju stanja poklicne izčrpanosti, ima čustvena podpora socialnega okolja. To se odziva na probleme, ki jih ima nekdo. Cohen in Wills (1985) pri tem ločujeta instrumentalno podporo (npr. denarna pomoč), podporo $z$ informacijami in nasveti, čustveno podporo ali podporo, ki izraža spoštovanje, kar pomeni dati drugemu vrednost, mu pokazati, da ga sprejemamo. ${ }^{10}$ Čustvena opora pomaga najti rešitve, spremeni naravo problema, zmanjša anksioznost. Maslach (1976) opozarja na to, da mnogi, ki tonejo $\mathrm{v}$ stanje poklicne izčrpanosti, pri sodelavcih iščejo nasvet pa tudi tolažbo. Takšna socialna opora nevtralizira čustva, napetosti, bolečino (str. 12). Seveda pa socialna podpora lahko anksioznost tudi poveča. Socialni krog je lahko tudi vir napetosti, izvor stresa in bolečine."

Socialna opora, ki jo nekdo v krizi prejme, je odvisna od tistega, ki jo daje, in tistega, ki jo prejema. Za to, da si nekdo pridobi pomoč, mora imeti primerne socialne spretnosti. Še več, pomoči smo deležni, če pokažemo, da smo si tudi sami pripravljeni pomagati, če imamo moč za to. Če pa prosimo za pomoč drugih, tako da poudarimo svoje potrebe in

V primeru, da se počutimo ogroženi, iščemo družbo tistih, ki jih je doletela podobna usoda. Gre za afiliativno težnjo, ki se kaže v stresnih situacijah. Ljudje se tedaj primerjajo med seboj in tako ugotavljajo, če so njihova čustva in razmišljanje ustrezni. V centru, ki bi se ukvarjal s preprečevanjem in zdravljenjem izgorelosti, bi bilo pomembno ustvariti priložnosti, da se srečajo in družijo ljudje s podobnimi delovnimi izkušnjami in podobno izobrazbo. Dva podjetnika ali odvetnik in ustavni sodnik si bosta med seboj v večjo oporo, kot bi si bili v oporo ljudje z zelo različnim referenčnim okvirom. Stanje izgorelosti namreč ni stanje, $v$ katerem bi se človek še naprej moral prilagajati. To je stanje, ko sam potrebuje pomoč. 
nemoč, če pripisujemo svoje težave zunanjim vzrokom, se nam lahko zgodi, da nas drugi zavrnejo. Če se nekdo obrača na druge po pomoč, to pomeni, da se želi iz situacije izviti, se z njo soočiti, jo premagati. Če je nekdo preobremenjen, lahko poišče pomoč: stvarno pomoč, nasvete. Pomoč socialnega okolja pripomore $k$ zmanjšanju poklicne izčrpanosti.

$\mathrm{V}$ nekaterih poklicnih okoljih celo velja, da si nekdo, ki prosi za pomoč in razkrije težave, načne svoj ugled in doživi neodobravanje predpostavljenih. Zato je nujno, da se lahko zateče po pomoč tja, kjer so za to usposobljeni in kjer je potrebo po pomoči moč izraziti. Drugače povedano, če stres ni socialno sprejemljiv, je prav mogoče, da navzočnost znanih oseb le še poglobi občutek napetosti. ${ }^{12}$ Tako je človek včasih raje sam, kot da se druži Če mu okolje tedaj nudi oporo, mu je nerodno. C̆e povzamemo, iskati pomoč pri drugih in približati se sodelavcem lahko pomeni priznati nezmožnost. Zato je toliko pomembneje, da so predpostavljeni dobro izobraženi zato, da pri drugem prepoznajo izgorelost in jim ponudijo roko v pomoč.

\section{POKLICNA IZČRPANOST OSEB, KI PREVZEMAJO VELIKO ODGOVORNOSTI, ALI BURNOUT MENEDŽERJEV}

Posebne obravnave naj bi bile $v$ povezavi $s$ poklicno izčrpanostjo deležne osebe, ki veljajo kot najbolj vnete za delo, so inventivne, samostojne, nase prevzemajo veliko odgovornosti, tudi za druge, ter navadno prejmejo prav malo pomoči. Tudi takrat ne, ko so že globoko v krizi. Gre za osebe, ki vodijo, povezujejo in navdušujejo druge ljudi za doseganje ciljev, kì jih načrtujejo.

Gre za osebe, ki so vztrajne in vzdržljive, pri čemer ima njihova vztrajnost vsaj tri razsežnosti: zavzetost in istovetenje z delom, sprejemanje izzivov in nadzorovanje. ${ }^{13}$ Vzdržljive osebe precej zdržijo, ker verjamejo v pomen in vrednost tega, kar počnejo, in v vrednost tega, kar so. Prepričane so, da lahko vplivajo na okolje. Vsega se lotijo radovedno in z zanimanjem. Za njih so spremembe običajen del življenja, izziv in ne grožnja. Vzdržljivost pa ni zmeraj enaka, odvisna je od konteksta. Če so take osebe zaposlene, je podpora predpostavljenih zanje pomembna. Če so sami ustvarili kakšen sistem, organizacijo, je zanje

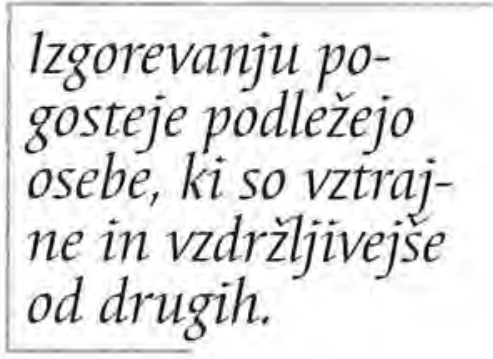
pomembno, da drugi čutijo podobno in so jim pripravljeni stati ob strani, bodisi stvarno, z nasveti ali kako drugače. Če se to zelo dolgo ne zgodi, postane zanje delo vir izgorelosti. Spremembe so vse hitrejše. Vodje morajo nadzorovati vse več dela in odnosov. Ker delo prinašajo tudi domov, morajo osebnostno rasti predvsem na delovnem področju, ki jim vzame največ časa. Podjetja se združujejo, moči se prerazporejajo, delničarji pritiskajo s svojimi zahtevami, delovna mesta izginjajo ali se povezujejo zaradi uvajanja tehnologije. Velikokrat menedžerji opravljajo več del hkrati. Vodenje ljudi je težko, Kdor vodi, se mora ukvarjati z vsemi - s tistim, ki je najmanj sposoben, s tistimi, ki dvomijo, so otožni, tekmovalni, zaljubljeni vase, nesrečni, ter $\mathrm{z}$ drugimi, ki so pretirano vneti za delo. Menedžer mora opredeliti cilje, jih organizira$\mathrm{ti}$, povezati in navdušiti ljudi zanj. Mora reševati konflikte, postaviti prednostne naloge, sprejeti odločitve o drugih,

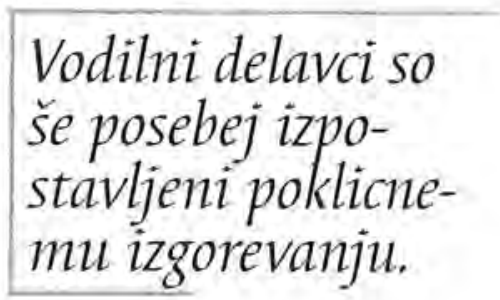
prenašati njihovo sovražnost in se ukvarjati s frustracijami, ki nastajajo $\mathrm{v}$ neprestanih stikih z ljudmi. Zaradi frustracij mnogi izgorijo. In tako doživijo čustveno in nevrološko krizo, ki je značilna za burnout.

Frustrativnih situacij je veliko, Čim večja je organizacija, tem dlje je potrebno, da se kaj zgodi in naredi. Ko se podjetja združujejo, se menedžerji znajdejo $\mathrm{z}$ še večjim številom lju- 
di. Krhki temelji pravne države, umik socialne države, prelaganje državnih pristojnosti na posameznike, društva, podjetja in druge družbene spremembe. Poleg tega pa še neprestano spreminjanje pogojev dela, proizvajanja in trgovanja, upad spoštovanja nekaterih poklicev, kar vse močno vpliva predvsem na one, ki niso odgovorni le zase in svoje bližnje. Kadar so od njihove zmožnosti odpiranja poti in sprejemanja odločitev odvisni mnogi drugi, včasih cela družbena področja, so frustracije, ki jih dolgo doživlja v spreminjajočih se družbenih pogojih, tolikšne, da jih nazadnje več ne zmore. Gre za osebe, ki imajo več znanja in izkušenj kot drugi, ki imajo za seboj veliko socialnega učenja in so si pridobile veliko izkustvenega znanja, kar je v njihovih očeh zadolžitev in zaveza. O sebi imajo navadno predstavo, da so etiěne, in tudi to jih zavezuje $\mathrm{k}$ neprestanim naporom in vztrajanju. Vrhu tega imajo razvit lokus kontrole. Vse to pripomore, da jim zmanjkuje moči, saj se zgodi, da predolgo vztrajajo v neki situaciji, ki je dejansko težko rešljiva. V vsakdanji govorici bi dejali, da gredo predolgo z glavo skozi zid.

Poklicna izčrpanost teh oseb je y škodo delovnih organizacij in družbenih področij. Močno zmanjša dohodek podjetja, četudi največkrat delo v podjetju ne zastane, saj gre za sistem, ki ga je takšna oseba sogradila in zgradila.

Zaradi posebne, osebne in poklicne preteklosti potrebuje oseba drugačno obravnavo kot tiste, ki so bile zaposlene $\mathrm{v}$ neki delovni organizaciji, drugačne modele pomoči. Poklicna izčrpanost ima simptome, ki jih je moč prepoznati pri mnogih, načini soočanja z njo pa so različni in osebni.

Značilnost, ki poklicno izgorelost $\mathrm{v}$ mojih očeh najbolj ločuje od stresa, je, da je to stanje nevarno za osebo samo, da ga spremljajo mučne nevrološke težave, in nikoli ni zares popravljivo. Človek, ki je preživel to stanje, se znajde v dolgotrajnem okrevanju, kjer se uči ljubeznivega odnosa do samega sebe in si pripravlja novo poklicno pot. Gre skozi preoblikovanje osebnosti in se navadno znajde z novim sistemom vrednot, obdan z novimi ljudmi in v novih okoljih. Na tej poti potrebuje spremljanje in izobraževanje. Stanje poklicne izgorelosti je namreč stanje, s katerim se organizem obupno brani, in ki med nekdanjim in novim življenjem postavi zaslon. Zaslon, ki ni prijeten niti za osebo samo niti za socialno okolje, ki ga, če se ne podredi njegovim novim kriterijem, ne more več doseči.

\section{LITERATURA IN VIRI}

Adams, J. S. (1965). Inequity in social exchange, V Berkowitz (ur.), Advances in experimental social psychology, 2, str. 267-299. New York: Academic Press.

Batson, C. D., Jones, C. H., Cochran, P. J. (1979). Attributional bias in counsellors diagnoses: The effect of resources on perception of need. Journal of Applied Social Psychology, 9, str. 377-393.

Blau, P. M. (1964). Exchange and Power in Social Life. New York: Wiley.

Bradely, H. B. (1969), Community based treatment for young adult offenders. Crime and Delinquency, 15 , str. 359-370.

Brouwers, A., Tomic, W. (2000). A longitudinal study of teacher burnout and perceived self-efficacy in classroom management. Teaching and Teacher Education, 16, str. 239-253.

Buunk, B. P., Schaufelli, W, B. (1999). Reciprocity in interpersonal relationships: An evolutionary perspective on its importance for health and well-being. V Stroebe in Hewstone (ur.), European Review of Social Psychology, 10, str. 260-291.

Cerney, M. S. (1995). Treating the sheroic treaters $\alpha_{+}$V Figley (ur.), Compassion fatigue: Coping with Secondary Traumatic Stress Disorders in those Who Treat the Traumatized, str. 131-148. New York: Brunner/Mazel.

Figley, C. R. (1993). Catastrophes. An overview of family reactions. V Figley in McCubbin (ur.), Stress and the Family, 2, Coping with

Catastrophe, str. 3-20. New York: Brunner/Mazel.

Freudenberger, H. J. (1974). Staff Burnout. Journal of Social Issues, 30, str. 159-165.

Freudenberger, H. J., Richelson. G. (1980). Burnott: How to Beat the High Cost of Success. New York: Pergamon.

Hemmelgarn, A. L., Glisson, C., in Dukes, D. (2001). Emergency room culture and the emotional support component of family centred care. Children's Health care, 30, str. 92-110. 
Karuza idr. (1982). Attribution Of Responsibility By Helpers And Recipients, V Wills (ur.), Basic Processes in Helping Relationships. New York: Academic Press.

Kiyyosaki, Robert T. (2002). Kvadrant denarnega toka. Ljubljana: Lisac \& Lisac.

Maslach, C. (1998). A multidimensional theory of burnout. V Cooper (ur.). Theories of Organisational stress. Oxford University Press, str. 68-85.

Organ, D. W., Moorman, R. J. (1993). Fairness and organizational citizenship behaviour: What are the connections? Social Justice Research, 6, str. 5-18.

Siegrist, J. (1991). Contributions of sociology to the prediction of heart disease and their implications for public health. European Journal of Public Health, 1, str. 10-21. Truchot, D. (1994). Attributions et représentations dans la relation d'aide. Paris, EHESS.

\footnotetext{
IRichard Senett: Corrosion of character:
}

${ }^{2}$ Tako se vedejo preveč socializirane osebe, pa tudi samozaposleni. Ti se ukvarjajo z intelektualnimi storitvami, in ker so sami brez sistema v ozadju na trgu dela, morajo biti popolni. Navadno težijo $k$ popolnosti. (Kiyyosaki, Robert T.: Kvadrant denarnega toka, Lisac \& Lisac, Ljubljana, 2002)

${ }^{3}$ Livet, Pierre: Emotions et rationalités en sciences sociales (slov. Custva in racionalnost v družbenih vedah), radijska oddaja, UTLS, 27. oktober 2002.

${ }^{4}$ J. G. (52) je izgubil vodilno delovno mesto, nadomestila ga je mlada ženska, ki jo je sam povabil $k$ sodelovanju. Zrušil se mu je svet, predstava o sodelavcih, $k i$ so z enim zamahom prećrtali vse njegovo izkustveno znanje in dolgoletno prizadevanje. Ni vedel, da obstaja širok družbeni trend, da se moške nadomešca z manj plačanimi mladimi ženskami. V izobraževalnem modu. lu zanj bi bilo moč predvideti spoznavanje paradigme družbenih sprememb in njihov vpliv na sfero dela in odnose v njej.

${ }^{5}$ T. B. (42) se je oglasil pri psihologu rekoč, da v bolnišnico, kamor je bil sprejet, ne sodi. „O, pa sodite, " je odvrnil psiholog, „a ne bomo vam dovolili, da ne sodelujete, zato vas odpuščamo. Ampak vedite, da se bova še srečala! «

${ }^{6}$ Sama sem pričakovala drugačen, bolj oseben in enakovreden odnos psihiatrov in psihologov. Ko sem svoje želje predstavila, mi niso mogli priti naproti, saj jih je doktrina ustanove zavezovala v drugačen model dajanja pomoči. Naše druženje se je končalo s pripombo: „Gospa, vi ste se odločili, da vam mi ne moremo pomagati.* To lahko preberemo drugače: „Vašega priěakovanja v zvezi z modelom dajanja pomoči ni moč zadovoljiti, kajli naš model je drugačen od tistega, ki si ga predstavljate vi, $\alpha$

${ }^{7}$ Tovrstne težave v zadnjih letih pospešenih družbenih sprememb in zmanǰ̧sane zmožnosti prilagajanja oseb v tretjem življenjskem obdobju vse pogosteje doživljamo tudi na Univerzi za tretje življenjska obdobje. Pojav, ki je bil v tej organizaciji civilnih odnosov v letih družbene stabilnosti sprva dokaj nepoznan.

${ }^{8} V$ času stavke zdravnikov so bili pacienti v neki naši bolnišnici deležni mnogih neutemeljenih in pikrih pripomb zdravnikov, kar je kazalo na to, kako ti zaznavajo odnose v svoji ustanovi.

${ }^{9}$ B. G. (58) je zašel v poklicno izčrpanost tudi zato, ker je njegovo veliko in uspešno farmacevtsko podjetje prevzelo neko močno večnacionalno podjetje. Njegovo podjetje je tedaj postalo odmaknjeno od informacij. Prej so a usem odločali sami, potem pa so odločtive prešle $v$ roke tujih oddaljenih vlagateljev. Omajal se jim je locus kontrole, pričel se je počutiti negotovega, utrujenega, izčrpanega, lotili so se ga simptomi depresije.

${ }^{10}$ Jaz sama in nekateri sopacienti - večinoma je šlo za osebe, $k i$ so jim instrumentalne rešitve razmeroma preproste, saj so jih zmeraj sami našli in izumili za druge - sem spoznala, da mi je bila najpomembnejša prav čustvena opora. Š več, do tistih, ki so mi namesto čustvene nudili instrumentalno oporo, ker pać drugače niso znali, gojim zamero, ki mi preprečuje, da bi bila z. njimi sproščena in zaupljiva, kakor sem bila nekoč. $V$ stanju poklicne izčrpanosti smo namreč nadise občutljivi za vrsto pomoči in način dajanja pomoč $i$, ki jo prejemamo. Neustrezna pomoč nam daje občutek, da so drugi zanikali naše bistvo in muke v času, ko smo se prvič zares obrnili nanje, ko brez njih nismo zmogli. Naše psiho-socialno okolje, $k i$ za take situacije nima znanja, pogosto ne ve, kako bi. Tu se odpira novo polje izobraževanja.

"Nekatere osebe iz mojega širokega socialnega okolja so z načinom ponujanja pomoči nevede povečale mojo bolečino in napetost. Bilo je, kot da grebejo po živi rani. Srečanju z njimi so navadno znova sledile nevrološke težave, slabost, bucike v konicah prstov, omedlevice ipd.

${ }^{12}$ A. B. (44) so hospitalizirali brez vednosti družine, ki je bila prepričana, da je njihova mati na daljši sluzbeni poti. Tudi ko je naredila samomor, se sinovi niso oglasili, da bi videli, kje je njihova mati preživela zadnje dni.

${ }^{13}$ Tega se socialno okolje ne zaveda. Ce oseba poklicno izgori, zanjo velja, da je premalo odporna za stres, da je preveč občutljiva. Ob tem pozabljamo, da je ta oseba zelo dolgo vzdržala napore, kakršnih večina niti ne poskuša, 